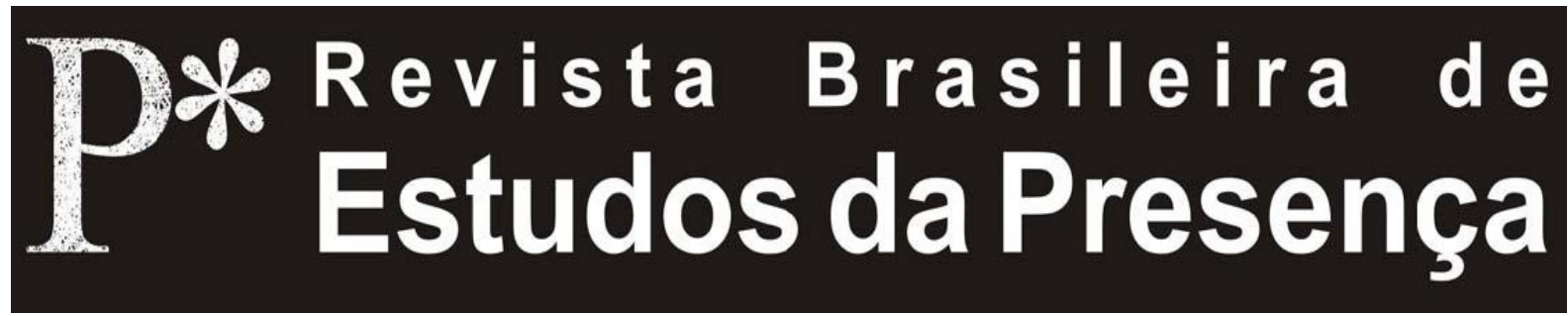

DOI - http://dx.doi.org/10.1590/2237-266033684

ISSN 2237-2660

\title{
A Arte do Encontro, uma Arte da Distância: de Thomas Richards e Mario Biagini a Jerzy Grotowski
}

\author{
Yannick Butel \\ Aix-Marseille Université I - AMU, Marseille, França
}

RESUMO - A Arte do Encontro, uma Arte da Distância: de Thomas Richards e Mario Biagini a Jerzy Grotowski - Este texto apresenta o ato teatral como uma passagem, a partir do testemunho das açóes de Thomas Richards e Mario Biagini que se inscrevem em um protocolo de trabalho nascido da herança de Jerzy Grotowski. Trata-se do instante no qual a arte como veículo, como escreveu Peter Brook, se confunde com a arte do encontro. Trata-se, ainda, do momento no qual a experiência transmitida pelo teatro provoca o desaparecimento das fronteiras e dos limites entre a cena, o ator e o espectador. A arte do encontro corresponde, entáo, à incorporaçáo do espectador no processo teatral que favorece um retorno da presença de si mesmo, o desaparecimento do estranhamento de si.

Palavras-chave: Jerzy Grotowski. Thomas Richards. Mario Biagini. Workcenter. Crítica Teatral.

ABSTRACT - The Art of the Encounter, an Art of Distance: from Thomas Richards and Mario Biagini to Jerzy Grotowski - This text presents the theatrical act as a passage, based on the observation of the actions of Thomas Richards and Mario Biagini that belong to a work protocol left by Jerzy Grotowski. This is the moment in which art as a vehicle, as Peter Brook wrote, merges with the art of the encounter. It is also the moment in which the experience transmitted by theatre causes the disappearance of boundaries and limits between scene, actor and spectator. The art of the encounter corresponds, then, to the inclusion of the spectator into the theatrical process which favours a return of the presence of oneself, the disappearance of self-estrangement.

Keywords: Jerzy Grotowski. Thomas Richards. Mario Biagini. Workcenter. Theatre Criticism.

RÉSUMÉ - L'Art de la Rencontre, un Art de l'Évitement: de Thomas Richards et Mario Biagini à Jerzy Grotowski - Témoin des actions de Thomas Richards et Mario Biagini qui s'inscrivent dans un protocole de travail né dans le prolongement de la parole de Jerzy Grotowski, l'acte théâtral s'apparente à un passage. C'est l'instant où l'art comme véhicule, comme l'a écrit Peter Brook, se confond à un art de la rencontre. C'est le moment où l'expérience transmise par le théâtre provoque la disparition des frontières et des limites entre la scène, l'acteur et le spectateur. L'art de la rencontre correspond alors à l'incorporation du spectateur au processus théâtral qui favorise un retour de la présence à soi-même, la disparition de l'étrangeté à soi.

Mots-clés: Jerzy Grotowski. Thomas Richards. Mario Biagini. Workcenter. Critique Théâtrale. 


\section{Notas Preliminares}

A alma mater, o que costumamos chamar mais comumente de universidade, convida os seus discípulos a um modo de comunicaçáo rigoroso em que a distância entre o objeto observado e o observador é necessária ao discurso científico, sempre pautado pela verificação. $\mathrm{O}$ discurso adquire, então, as qualidades exigidas, entre as quais as que impóem uma demonstraçáo do saber, da análise e do olhar crítico do observador. Ele deve ser persuasivo. O objeto, a obra ou a prática artística comentados acabam por desaparecer um pouco, o discurso póe em primeiro plano uma linguagem teórica que, frequentemente, esconde parcialmente o objeto. Com frequência, o discurso acadêmico - preso em uma gramática, um léxico, um estilo, uma moldura argumentativa e explicativa, que lhe permite pertencer ao círculo dos professores e mestres - perde, então, uma certa espontaneidade, uma forma de ingenuidade, uma relação com o 'contar histórias', que é tão importante para ressaltar o caráter vivo da experiência que foi experimentada e da qual se fala. O discurso é, então, mutilado da vivacidade e da vitalidade da experiência vivida.

Feitas essas advertências e levantadas essas observaçóes, eu gostaria que este artigo permitisse reconciliar os dois aspectos que acabamos de distinguir: de uma parte, o rigor universitário; de outra, a relação sensível e afetiva que se mantém com o objeto, que é objeto da análise crítica.

Desse modo, propus à Tatiana Motta Lima falar de Jerzy Grotowski e do trabalho do Workcenter of Jerzy Grotowski de Thomas Richards e Mario Biagini. Tudo isso articulado ao tema da arte do encontro ${ }^{1}$. Tratar-se-á, neste caso, de falar sobre a arte do encontro e de tecer relaçóes entre a obra teórica de Jerzy Grotowski e as de Thomas Richards e Mario Biagini. Tratar-se-á, também, de questionar o encontro do espectador com essas obras e de se aventurar nesse espaço comum formado pela união de duas coisas diferentes: a obra e aquele que a observa.

\section{Ao Acaso dos Encontros}

Em 2004, no período de junho e julho, o Workcenter of Jerzy Grotowski, Thomas Richards e Mário Biagini esteve em Caen para apresentar Tracing Roads Across, apoiado, entre outros, pelo Centre Dramatique National-Comédie de Caen, dirigido por Eric Lacasca- 
de dentro do programa Impulse in France. Impulse é um programa de trabalho que incluía conferências abertas ao público, trocas de trabalho, performances e demonstraçóes de obras. A esse programa se acrescentava a projeção de filmes documentários: Art as vehicule, Downstairs action, filmes que propunham um olhar sobre o trabalho do Workcenter. Esses filmes eram chamados de obras criativas. Houve, ainda, a apresentação de três formas cênicas: Action, um material relacionado às artes performativas construídas com e em torno dos cantos vibratórios, como explica o seu criador Thomas Richards; The Twin: an Action in creation, uma forma baseada no trabalho interno do grupo e feita em contato direto com as testemunhas; e, por fim, dentro do projeto The Bridge developing theatre arts, a apresentação de Dies Irae, dirigido por Thomas Richards e Mario Biagini. O conjunto da programação e das obras provinha de uma reflexão formulada em maio de 1998 sobre a Arte como veículo. Sobre a Arte como veículo ${ }^{2}$, é preciso compreender - como os escritos de Thomas Richards e Mario Biagini apontam - que se trata "[...] de uma indagação sobre a ponte lançada e esculpida com o material das artes teatrais, uma ponte que se estende do mundo do teatro às investigaçóes sobre a Arte como veiculo" (Richards; Biagini, 2004).

Uma explicação que podíamos ler ainda de uma outra maneira no programa - que foi distribuído durante sua residência na Fonderie em Mans, no Théâtre de Radeau - que apresentava as diferentes atividades e que eu gostaria de lembrar aqui:

O esplendor da vida está constantemente à espera de cada um de nós em toda a sua plenitude, mas velado à visão, enterrado nas profundezas, invisível, distante. No entanto, ele está aqui, nem hostil, nem mal intencionado, nem surdo. Se o convidarmos com palavra certa, pelo seu verdadeiro nome, ele virá. Essa é a essência do teatro, que não cria, mas convida (Richards; Biagini, 2004).

Naquela época, eu era um jovem professor da universidade e, também, crítico de teatro. O jornal no qual eu trabalhava havia me pedido para escrever sobre o trabalho do Workcenter. Eu havia previsto fazer um levantamento a respeito, pois tinha ouvido falar desse trabalho em ligaçáo direta com o de Jerzy Grotowski (esse "mestre idealizador de obras", conforme Raymonde Temkine (1989, p. 10)). De Grotowski, eu conhecia somente os vídeos de seus espetáculos, os textos e comentários que haviam sido escritos sobre ele ou as conferências que ele tinha ministrado. Com alguma emoção 
e excitação eu estava indo descobrir o trabalho daqueles que, não desejando viver de renda ${ }^{3}$, como gurus grotowskianos, começaram uma nova Ação ${ }^{4}$, através da composição de obras que levavam em conta os espectadores.

Gripado nesse início de primavera, corri o risco de perder tudo e não ver nada. Decidi ficar na cama, febril e triste por perder o encontro. Foi uma ligação telefônica de Mario Biagini que fez tudo mudar. Mario pediu-me que fosse, mesmo doente, ele disse. Eu me dei conta de uma evidência, eu tinha um encontro com uma história. Naquele dia, encontrei dois amigos. Alguns dias mais tarde, Thomas e Mario comeram comigo em minha casa. Nós passeamos pelo jardim e Mario me dava explicaçóes de especialista sobre a flora, convidando-me a cuidar da terra com remédios italianos.

Esse primeiro encontro foi o início de uma série em que, ao chamado deles, eu me viro para poder encontrá-los. Eu me lembrarei por muito tempo dessa perambulaçáo no jardim. Pensando bem, ela parece $O$ passeio do cético de Denis Diderot (1747). Um passeio filosófico, em que diante de minhas modestas plantaçóes e árvores, tudo era um pretexto para conversa. Era um passeio para começar a falar. Para falar, talvez, de uma forma diferente. De certo modo, para re-aprender a falar. Náo foi uma constatação que fiz imediatamente, mas que se tornou evidente, mais tarde, em duas ocasióes, quando o Workcenter foi recebido por François Tanguy no Théâtre du Radeau em La Fonderie ${ }^{5}$, em Le Mans. Dois novos encontros nos quais se tratava de formar uma comunidade que desejasse pensar o teatro, mas não somente o seu próprio teatro. Eu me lembro, então, do primeiro desses dois encontros em que, sob a direção de Antonio Attisani (e seu cachorrinho que parecia observar os debates), eu comecei a falar tomado de uma emoção muito grande, da qual eu jamais tivera conhecimento. Era primeiro de julho e, no fim de minhas consideraçóes, confuso e emocionado, Mario e Thomas vieram me reconfortar. Thomas me disse uma coisa que ainda me perturba: "Yannick, foi muito bonito o que você disse. Você tem uma alma". Quando eu penso em tudo isso ainda hoje, e relembro-o sem pudor, é somente para enfatizar que há encontros na vida que podem parecer ocasionais e nos quais algo da vida está em jogo.

Entre os convidados na Fonderie, com o Workcenter, estava Michelle Kokosowski, conhecida como Koko. Trata-se de um nome de guerra para essa mulher que trabalhou com Jerzy Grotowski, que o 
levou à França e que sempre lhe foi fiel. Koko, que quer dizer aqui e agora em japonês, é o que se pode chamar de um expoente do teatro francês, mas também do teatro europeu e internacional. Ela esteve muito próxima da direção do Festival de Nancy e fundou a Académie Expérimentale des Théâtres-AET, que funcionou de 1990 a 2001. A $\mathrm{AET}^{6}$ foi uma aventura humana e, também, uma aventura nômade, com mais de 162 açôes $^{7}$ em que os Mestres ${ }^{8}$ do teatro internacional vinham encontrar jovens diretores inquietos com sua prática. Aqui, a maneira de fazer teatro encontrava-se com um desejo de pensar a prática do teatro em seus fundamentos. Koko, quando fala dessa época e dessa aventura, resume em uma só palavra o objetivo desses doze anos. Ela fala de Transmissão. E essa palavra também remete, para ela, à palavra Memória.

Eu encontrei Michelle Kokosowski quase por acaso, em 2002. Ela estava depositando os documentos da Académie Expérimentale e do acervo pessoal dela no IMEC. Nossas primeiras discussóes foram seguidas por muitas outras, frequentemente profundas. Foi ela que me falou a respeito de Jerzy Grotowski, do seu eremitério em Pontedera e do que se passava lá. Ela era a testemunha: a testemunha de uma obra, de uma prática e da vida de um homem. Ao escutá-la contar essas histórias, eu percebi que nossas conversas tinham um objeto, pois eu náo deixava de pensar e refletir sobre tudo isso bem depois que Koko ia embora. Eu acredito ter aprendido com Michele Kokosowski que há, numa discussão, num encontro para debater, uma espécie de ética. No mesmo sentido de ethos, em grego, que quer dizer um modo de ser no seio de uma comunidade. Eu não me lembro com muita clareza do dia em que ela falou da prática grotowskiana do encontro. Nós estávamos, parece-me, no terraço do Café de France, na Praça da Bastilha, em Paris. Ela terminava de me falar sobre um texto de Jerzy Grotowski, Tu es le fils de quelqu'un (1989). E eu não sei por que, ela me disse que quando Grotowski convidava alguém para fazer uma conferência em Pontedera, ele o recebia e, sem o prevenir, colocava-o diante do público, retirava-lhe a mesa e a cadeira de conferencista e os papéis da comunicaçáo previamente preparados. O conferencista permanecia de pé sem suas notas diante do auditório, no vazio, diante dos espectadores, de mãos livres. $\mathrm{E}$ Jerzy Grotowski pedia que iniciasse a conferência dessa maneira, de máos livres, sozinho diante de todos. E o convidado devia falar, talvez de memória, talvez com a lembrança do que havia escrito e 
preparado. Mas, longe das frases preparadas e escritas, longe de um pensamento encarcerado na escrita e longe de um sopro preso à sintaxe. Ele devia encontrar em si mesmo a força, a energia, a raiz das palavras e de seu pensamento libertado da gramática e da retórica. E, provavelmente, o conferencista deixava surgir algo de si mesmo, algo que ele abrigava em si.

Possivelmente, Jerzy Grotowski, ao fazer esse gesto de retirar do conferencista tudo que ele havia preparado, pensava sobre aquilo que procurava sem cessar e sempre: "[...] eu não quero descobrir alguma coisa nova, mas alguma coisa esquecida" (Grotowski apud Temkine, 1989, p. 11).

Ao ler essa frase, penso que, se a aplicarmos à fala, Grotowski buscava então uma fala consciente de como ela vem, de como ela aparece e do porquê ela surge. Seria uma fala que nada mais teria a ver com o artifício, com o simulacro da inteligência, com o estilo. Mas, seria uma fala autêntica, vinda do mais profundo de si. Como ele ainda escreve em Tu es le fils de quelqu'un, não se trataria mais de encontrar "[...] uma competência técnica, mas uma competência em você mesmo" -, entenda-se "em si mesmo" (Grotowski, 1989, p. 25).

Alguns anos mais tarde, na Fonderie de Le Mans, essa história grotowskiana me viria à mente enquanto falava sobre o trabalho de Thomas Richards e de Mario Biagini.

Diante do público reunido, eu abandonei as minhas anotaçóes, a minha conferência, o meu papel de professor. Era como se Grotowski estivesse lá e tivesse me obrigado a fazer dessa maneira. Assim, eu comecei a falar. Era a primeira vez em que eu falava com a sensação de que era necessário fazer compreender o lugar de onde eu falo. Eu tinha medo, pois tudo isso era novo e eu nunca havia me imposto uma tal experiência. Mas, se eu tinha medo, no momento no qual eu tomei a palavra eu me mantive firme, de pé. Grotowski diz: "o homem é aquele que se mantém de pé” (1989, p. 19). Eu deixava, entâo, vir ou retornar o meu cérebro reptiliano (Grotowski, 1989, p. 17): uma energia primária que se pode assimilar a um impulso original. Tratava-se de uma palavra reptiliana que ia buscar dentro de mim o que havia para ser ouvido.

Essas duas histórias - que é preciso chamar de encontros - me servirão para desenvolver minha proposta sobre a arte do encontro, uma arte da distância. Se elas possuem uma característica autobiográfica e demandam certa falta de pudor, se convocam a figura de Jerzy 
Grotowski e a de Michelle Kokosowski, assim como as de Thomas Richards e de Mario Biagini, elas enfatizam, sobretudo, um gesto determinante. $\mathrm{Na}$ verdade, nos dois casos, essas histórias contam sobre uma exigência, uma formação e uma transmissão. Uma exigência referente à vontade que Mario e Thomas tinham de falar comigo e de me fazer falar. Uma formaçáo, também, pois a conversa com Michelle Kokosowski não é de maneira nenhuma estranha a isso.

Enfim, essas histórias falam a respeito da transmissão, pois, nos dois casos, o que nos unia era a obra teórica ${ }^{9}$ de Grotowski, e a obra artística e teórica, de Thomas Richards e de Mario Biagini. Ou seja, um diálogo com a arte como veículo que também teoriza a questáo do lugar do espectador, daquele que assiste e que é testemunha da obra. Portanto, parece-me possível afirmar que o encontro com Michelle Kokosowski, Thomas Richards e Mario Biagini diz respeito a algo da ordem de um ensino informal. Na conversa pessoal, ou através do contato com a obra, havia, indistinto e, no entanto, presente, um ensinamento. Quer dizer, uma atenção e uma generosidade transmitidas por intermédio desses pequenos acontecimentos, que são sempre uma preparaçáo. Em outras palavras, e dito de outra maneira, eles me dispuseram a ouvir e falar. Eles me colocaram na posição de receber, de ver e de ser. Definitivamente, tratava-se, assim, de transmissáo. Uma transmissão que se exerceu em parte, à margem das obras, mas sempre no âmbito delas. Assim, Michelle, Thomas e Mario me transmitiram uma palavra que influenciou a maneira como vou falar.

Não se trata de formação do espectador, essa é uma maneira de educar e adaptar o espectador a todas as formas estéticas, poéticas e cênicas. Na verdade, trata-se de uma forma de iniciação, talvez de instrução, que me permitiu, no momento da recepção dessas obras, ser capaz de compartilhar um modo singular de trabalho. $\mathrm{Na}$ arte do encontro da qual falo, a transmissão permitiu de fato um encontro com a obra. Quer dizer que ela permitiu a redução da distância entre o espectador e a obra, no espaço comum que é o ato teatral, a tal ponto que se o espectador é necessário à obra, a obra se torna também necessária ao espectador. A tal ponto que, sobretudo, no momento do encontro, aparece um espaço mental comum que me conduz a descobrir, através da obra, algo que está guardado em mim e que a obra deixa aflorar. Trata-se, precisamente, de um espaço intermediário no qual a noção de obra assim como a de identidade do espectador se dissolvem parcialmente no tempo do encontro. 
Momento de dissolução que não significa o desaparecimento de um ou de outro, mas simplesmente uma mutação, uma transformação, talvez uma metamorfose das relaçóes complexas induzidas pela arte: a obra de arte.

Ao evocar o efeito dessas histórias em $\mathrm{mim}^{10}$, esse eu plural como diria Roland Barthes (1984, p. 47), é preciso dizer que a descrição que acabei de fazer pode causar certa confusão. Poder-se-ia crer que eu estava sendo formado. Não foi nada disso e se eu tivesse que confessar precisamente do que se tratava, eu diria que tinha sido colocado no estado de iniciante, daquele que começa. Eu compreendi isso no dia em que, encontrando Thomas Richards e Mario Biagini na Fonderie de Le Mans, eles falavam comigo ao mesmo tempo em que me conduziam para uma das salas da Fonderie. Lá, Thomas Richards apresentava The Living Room ${ }^{11}$.

Os dois me acompanhavam. Nós caminhávamos e falávamos sobre tudo. No meio da sala, eles pediram que eu me sentasse em uma banqueta situada ao lado de uma mesa. Eles estavam agachados. Alguém veio e me ofereceu um café. Nós falávamos. E, de repente, Thomas recuou lentamente e mudou fisicamente de atitude e de rosto. Do mesmo modo, Mario mudou. Duas pessoas vieram retirar a mesa. Eu estava sozinho, sentado no meio da sala e todo mundo estava ao redor. The Living Room começava e eu me encontrava no meio do que ia acontecer. No início, fiquei constrangido. Eu não sabia o que fazer: continuar ali ou me juntar aos espectadores. Então, decidi me manter sentado porque pensei que isso me daria uma experiência. $\mathrm{Na}$ proximidade de seus cantos, de seus corpos, de seus movimentos, de seus rostos que vinham tão próximos a mim... eu senti, um olá, um envolvimento, um gesto amigável e acolhedor. E eu procurei o que poderia lhes oferecer em troca. Eu procurei no meu espírito, mas não encontrei nada. Mas sei que o meu corpo se endireitou, se esticou. Durante uma hora senti a minha coluna vertebral. E náo sei se eu fazia isso conscientemente ou se algo me levou a fazeê-lo. E também sei que eu escutei e senti as ondas no meu corpo esticado. Eu não estou analisando nada. Eu relato somente uma experiência de iniciante.

Hoje, enquanto conto essa última história, acredito que posso dizer que aprendi alguma coisa nesse mesmo instante.

Eu aprendi que o trabalho de Thomas e Mario não começa apenas quando a forma artística se dá a ver no momento do espetá- 
culo, mas que o trabalho deles ultrapassa a cena. O que quero dizer é que enquanto caminhávamos em direção à sala, conversando, até o momento em que eu estava sentado sozinho, já havia todo um processo em desdobramento. Caminhar, falar, fazer amizade, viajar para se encontrar, isso também faz parte da prática deles. Nós formamos um todo. Nós somos de todos os tempos e de todos os espaços, indivisíveis. Nós somos um processo vivo presente no tempo do espetáculo. De certo modo, há uma anulação de todos os recortes temporais. Não há mais passado, presente ou futuro, pois o ser da pessoa: seus pensamentos, suas ações, suas experiências, não é algo que se possa recortar ou isolar, mas é Um. Na verdade, é o conceito mesmo de espaço, criado no teatro sobre a divisão cena/sala, que, do mesmo modo, é anulado. E, nesse caso, seria necessário pensar sobre a questáo do alcance: uma superfície e um plano mais generoso que somente aquele do espaço da cena. Mais generoso e mais complexo do que o teatro quando ele náo é mais do que um lugar de reunião que obedece somente à diversão espetacular e crítica.

Assim, a prática de Thomas Richards e Mario Biagini lembranos que nós formamos uma unidade, um todo, uma totalidade. Eles nos convidam a fazer um balanço e a nos lembrar daquilo que a vida cotidiana náo nos permite mais pensar. Eles nos convidam a reinvestir naquilo que a vida cotidiana nos fez esquecer. Nós somos um conjunto contínuo. Nós somos uma raiz ${ }^{12}$. Uma fonte.

A consequência dessa constatação é que, nesse processo, está fora de questáo falar sobre o espectador como uma identidade e um momento que remete a um recorte, a uma função e a um papel. Se nós não somos mais espectadores, entáo, nós somos somente um serali, e o protocolo realizado por Thomas Richards e Mario Biagini nos convida a senti-lo, a lembrá-lo, a vivê-lo.

No meio da sala, longe dos espectadores pela minha localização e próximo aos atores devido à minha ocupaçáo do espaço, muito mais espectador do que ator, parece-me, em retrospectiva, que eu posso explicar o que estava em jogo no trabalho de Thomas Richards e de Mario Biagini a partir do texto de Jerzy Grotowski, intitulado L'art du débutant (1978).

Nessa conferência rara e essencial de 1978, Jerzy Grotowski já tinha abandonado o que ele chama de teatro dos espetáculos. Ele passou por diferentes etapas ${ }^{13}$ e pesquisava linguagens com o objetivo de encontrar uma técnica, um mundo de signos para tentar 
escapar dos protocolos teatrais que ele julgava muito distantes da autenticidade. No seu trabalho, trata-se de se liberar do mundo e do poder da civilização que colonizam o corpo. Ao recorrer a diversos exercícios, Jerzy Grotowski parece ter atingido o seu objetivo: estar no limiar, ou seja, no começo. Ele escreve: "estar em permanência no início" (1978, p. 3). Aos meus olhos, isso não significa no início de um aprendizado. Não, "estar em permanência no início" quer dizer ter realizado o aprendizado e estar como alguém que, quando se encontra em contato com uma experiência - talvez uma nova experiência -, mantém a mesma postura. Pois estar "em permanência no início" significa

[...] estar no começo [...] estar no começo é se deixar realmente estar naquilo que se faz, que se descobre, naquilo que se percebe [...] E o que é preciso fazer é criar condiçôes nas quais o aprendizado não seja o mais importante, e sim a presença de seres humanos muito diferentes e que, mesmo não dispondo de nenhuma linguagem comum, possam, graças a essa presença, decolar em uma espécie de voo comum (Grotowski, 1978, p. 5).

Em outras palavras, aquilo a que Jerzy Grotowski convida é o ter aprendido a se desdomesticar, ter se tornado disponível e náo estar na posição daquele que vai pensar ou reagir, mas sim daquele que é novamente capaz de pensar. "Estar em permanência no início" é, de fato, estar de pé e receptivo, sem a priori, pois a "[...] questão do começo está ligada permanentemente à questáo da presença do original", como diz Grotowski (1978, p. 5).

De certo modo, uma palavra seria conveniente a esse estado se ela não fosse frequentemente associada a um sentido de idiotice ou de ignorância. Como Nietzsche (1949), de um certo ponto de vista, Grotowski espera uma forma de ingenuidade. Quer dizer, uma qualidade essencial, uma disposição original, que longe de ser a do ignorante ou do idiota é, antes de tudo, aquela de alguém cujo julgamento é livre e cujo ser é, por disposição, e após um treinamento, sensível à experiência vindoura.

Falar de começo e permanência, na verdade, é imaginar um sujeito que esteja sempre com a sua escuta voltada para o devir, para a observação do que acontece, para a descoberta da experiência imediata e não num ato de razão pensado e calculado.

São esses os seus desejos quando ele escreve: "[...] quando se fala em técnicas das fontes ou do começo, não se trata de jeito nenhum 
de procurar onde se encontram as fontes, mas isso quer dizer estar no início" (Grotowski, 1978, p. 3).

Certamente, as palavras de Grotowski se referem ao ator em primeiro lugar e imagino que alguém possa me repreender ${ }^{14}$ por fazer um paralelo com o espectador.

É verdade que nossa coluna vertebral alongada não tem, sem dúvida, a priori, nada a ver com a de Ryszard Cieslack ${ }^{15}$ em $O$ Príncipe Constante.

A pesquisa de Grotowski se dedicava - compartilhemos essa evidência - ao trabalho do ator e como ele escreveu, "[...] o método de formação do ator pretende ensiná-lo a eliminar os obstáculos colocados no trabalho psíquico pelo próprio organismo" (Grotowski, 1965, s. p.).

É evidente que o espectador jamais foi poupado de um questionamento táo preciso. E isso, sem dúvida alguma, porque a perspectiva filosófica de Jerzy Grotowski, no que concerne ao teatro, sua função, seu espaço no mundo, sua missão, leva-o a pensar sobre a presença do espectador no espaço teatral. Não somente a presença física e material - digamos, corporal - mas, também, e, principalmente, sua presença no teatro. Isso quer dizer, o modo de ser que lhe permite estar na proximidade orgânica da experiência cênica e teatral.

Nessa perspectiva, nessa preocupação de favorecer uma recepção total do evento artístico, na busca de um instante comum e de um compartilhamento da ação, Jerzy Grotowski desenvolveu algo que nomearei de uma arte do encontro e que, por extensão semântica, deve-se também considerar como uma arte da distância.

\section{Da Arte do Encontro e da Distância}

Numerosos traços dessa pesquisa e desse trabalho estão espalhados aqui e acolá. Dito isso, será, em parte, uma contribuição impossível de encontrar hoje que nós evocaremos para prosseguir nosso estudo.

Foi em uma conferência realizada em 15 de outubro de 1968, na Academia Polonesa das Ciências de Paris, sob a presidência do diretor do Conservatório de Arte Dramática de Paris, Pierre-Aimé Touchard, que Jerzy Grotowski vai pensar a concomitância do trabalho do ator e do espectador. $\mathrm{O}$ texto de sua apresentaçáo foi nomeado com o título: O teatro contemporâneo em busca do rito (Grotowski, 1968). 
Nesse artigo, enquanto Pierre-Aimé Touchard expressa seu reconhecimento a Jerzy Grotowski, confessando que a prática do diretor é saudada como uma fonte que restitui a todos respiração e oxigênio, Jerzy Grotowski responde ao Presidente da conferência tecendo consideraçóes a respeito do teatro e o rito.

Em seu discurso, Jerzy Grotowski retoma um dos protocolos de trabalho que ele pôde observar. Ele começa pela retificação do título ou do tema da sessáo, insistindo sobre a ordem dos elementos da frase a busca do rito no campo do teatro, enfatiza ele. Em seguida, ele faz uma crítica breve e, logo após, uma autocrítica, quando se refere à época em que era um jovem diretor em Cracóvia. Depois, ele acrescenta:

[...] eu tinha uma certa imagem do teatro possível, uma imagem que foi, de certo modo, formada em oposição ao teatro existente, esse teatro muito cultural, no sentido convencional, um produto do encontro de pessoas instruídas: pessoas que se ocupam das palavras, dos versos, dos gestos, do cenário, da iluminação, etc., e, em seguida, outras pessoas bem instruídas que sabem que se deve ir ao teatro porque se trata de uma espécie de obrigação moral ou cultural. No fim de tudo, todos saem desses encontros bem instruídos, mas nada de essencial pode ocorrer entre essas pessoas. Cada um continua prisioneiro de algumas convençóes, pensamentos e ideias relativas ao teatro (Grotowski, 1968, p. 14).

Tudo, nessas poucas linhas, está dito e nos conforta em nossa ideia de uma arte do encontro. Em duas passagens, a palavra encontro está articulada. Além disso, as comunidades do teatro e do espectador são igualmente convocadas e pensadas em conjunto. $\mathrm{Na}$ sequência, Jerzy Grotowski faz uma análise crítica do funcionamento do teatro que repousa, in fine, sobre um público "instruído" e um teatro de "convençôes" que remetem a uma relação nos moldes da prisão: prisioneiro das convençôes. Em uma outra tradição que ele mesmo experimentou, esse "teatro existente" (cito-o novamente) náo serve na verdade a nada, não tem nenhum objetivo, não serve para nada a não ser para alimentar uma mitologia falida em que a cultura substitui a arte.

Em seguida, no artigo, Jerzy Grotowski se propôs a considerar uma "espontaneidade primordial" que ele pensa ser "uma via em direção ao teatro vivo" (Grotowski, 1968, p. 14). Ele vai além e diz que se deve "[...] confrontar os atores e espectadores diretamente, que se deve buscar uma troca, seja no domínio da linguagem seja 
no domínio da linguagem teatral" (Grotowski, 1968, p. 14), e como ele havia feito nos anos 1960, após alguns espetáculos ${ }^{16}$, “[...] buscar essa organizaçáo do rito entre os atores e os espectadores, quando eu encontrei um arquiteto inteligente" (1968, p. 14). Desse modo, ele preconiza para cada espetáculo a organização do espaço: “[...] deve-se abandonar essa ideia da cena e da sala como duas coisas absolutamente divididas, deve-se utilizar o jogo do ator como stimulus para colocar o espectador em jogo" (1968, p. 14) a fim de escapar do "teatro banal" ou de "cair na representaçáo de si mesmo" (1968, p. 15).

A visão de Jerzy Grotowski é clara. A questão não é formar $o$ espectador, mas modificar as condiçóes do encontro do espectador no momento da percepçáo da obra. Trata-se de conseguir, assim como para o ator, a diminuiçáo da distância entre o espectador e o objeto com o qual ele se encontra em contato. Cito-o novamente: "[...] pode-se questionar qual é o destino do espectador assim como se pode questionar qual é o destino do ator. O destino do espectador é ser um observador e, mais ainda, é ser uma testemunha [...] de participar de uma cerimônia [...] é a função da testemunha autêntica [...] ser testemunha é não esquecer [...]" $(1968$, p. 16).

É com esse objetivo que Jerzy Grotowski manifesta sua preocupação com a arquitetura teatral, sua preocupação com a divisão do espaço, a criação de um espaço virgem para "dar ao espectador a chance de uma participaçáo emotiva direta" (1968, p. 16). É o que ele chama de um espaço de "crueldade" ou de "pensamento selvagem". Isso significa uma arte teatral que náo mente para o espectador, um espectador que, no contato com essa obra, náo pode mais mentir para si mesmo. Um espaço que poderia ser qualificado, enfim, como autêntico ${ }^{17}$ e uniria uns e outros pela atração de um "cristal do desafio, algo muito puro, como a experiência dos nossos ancestrais, a experiência dos outros, como a voz do abismo que fala" (1968, p. 18), como sublinha Grotowski. Trata-se para ele de construir o que ele chama de um "cristal do signo", um "esboço de vida" (1968, p. 20).

Haverá contestaçóes a isso, a esse desenvolvimento e a essa interpretação, pois quando Jerzy Grotowski se refere ao "cristal do signo", ele fala de retirar do texto (que ele aproveita para o teatro) tudo o que náo lhe dá vitalidade e inquietude e que não lhe permite acessar a autenticidade. Trata-se de retirar tudo o que náo permite fazer surgir a "voz do abismo", como ele bem sublinha. 
É justo, mas, ao mesmo tempo, é preciso lembrar que, de maneira recorrente, Jerzy Grotowski buscava uma linguagem que tocasse tanto o ator quanto o espectador. Uma linguagem que, um deles, o ator, articularia e o outro, o espectador, fosse capaz de ouvir. Uma linguagem que seria definitivamente comum: no momento de dizêla, ela seria ouvida. O dito e o ouvido como as duas faces necessárias à linguagem. Uma linguagem que Grotowski disse só ter "podido encontrar após a experiência" (1978, p. 4), na experiência. Uma linguagem que nasceria, talvez, da qualidade do silêncio que precede o momento em que a palavra ressoa. Um pouco como descreve o jovem estudante americano Thomas Richards quando ele menciona o seu encontro com Jerzy Grotowski e se lembra de suas primeiras sessóes em Pontedera: "[...] havia uma qualidade de silêncio específica antes de cada uma de suas respostas que náo era nem um pouco artificial" (Richards, 1997, p. 8). O silêncio no qual o espaço mental e sonoro é um degrau para acessar o espaço da linguagem e assim escapar do discurso artificial. O silêncio do qual Hölderlin falou em Fête de Paix (Hölderlin, 1967) e no qual ele diz: "[...] no retorno do silêncio nasce uma língua" (1967, p. 861).

No processo colocado em jogo por Jerzy Grotowski e, em seguida, pelas testemunhas que são Thomas Richards e Mario Biagini, no instante da obra em que o espectador é uma testemunha e náo mais um observador distante e afastado, no tempo da obra onde o espaço deve ser pensado como uma nave que abriga cada um... o silêncio e a linguagem são indiferentemente a causa e a consequência, indiferentemente o início e o fim, pois eles formam uma unidade necessária à realização da obra que é, é preciso enfatizar, uma forma e uma testemunha que se encontram e compartilham uma linguagem desconhecida até entáo. Talvez, esse instante do encontro seja o signo, o sintoma... da compreensão. Algo que me direciona àquilo que me habita - nos habita - e me dará a chave de onde mora o ser. É maravilhoso pensar que nossas reunióes, no espaço teatral, vão nessa direçáo e que elas me permitem ir ao encontro, entre todos e com todos, do que eu sou, naquele momento em que eu estava.

Ao escrever isso, eu penso em meu amigo Robert Misrahi, o autor de uma obra filosófica importante e um dos mais relevantes estudiosos de Spinoza. Em um livro raro, Construction d'un château, Robert Misrahi escreve na forma de um ensaio iniciático e épico como "aquilo que nos constrói" resulta dos nossos encontros e se 
apoia em nosso desejo de fazer existir em nós um "pouquinho de luz" (Misrahi, 2006, s. p.).

No meio da sala, sentado na minha banqueta, quando Thomas e Mario me deixaram, esse silêncio era inicialmente visível e sensível, enquanto ele fazia surgir uma linguagem comum que eu ainda não imaginava. Pois, mais que a solidão que eu pude experimentar naquele breve instante, quando o canto começou a soar e Thomas começou a dançar lentamente decompondo cada movimento como se fosse uma marionete flexível, o canto ${ }^{18}$ murmurado e recitado conectou em mim "o coração e a mente" (Richards, 1997, p. 69). E não eram o canto e as palavras, que continuaram desconhecidas para mim, que eu pude ouvir. Mas foi, e não há outra palavra além dessa que mastigo e rumino, um encontro com algo que, sonoro externamente, fazia emergir em mim uma voz interior expressiva, alegre, grave e esquecida e que sempre estivera presente. Eu digo isso porque ingenuamente devo admitir aqui que essa sensação, essa vibração, eu já a tinha experimentado diante dos elementos rudes e infinitos que a natureza de vez em quando nos permite perceber. Eu a senti intensamente, quando na extensão do muro de Adrien, no pântano e na proximidade com a fronteira da Escócia, passei por extensóes vazias, esculpidas pela chuva e pelo vento e por milhares de anos. Novamente eu a senti diante do Oceano Atlântico, na ponta da regiáo de Finistère Sud quando a imensidão cinzenta do oceano nos remete à justa medida da nossa escala: nossa fragilidade. E eu também a tinha experimentado no topo das montanhas que escalei sozinho no verão. Lugar de solidão e de intimidade com as forças e as energias do mundo etéreo e terrestre.

São exemplos que poderiam levar o leitor a imaginar que descrevo aqui a maneira pela qual Kant descreve e define o Sublime em A faculdade do juizo (Kant, 1993). Talvez sim, mas de maneira mais informe, pois enquanto tento definir o que acontece no instante do canto e o que eu nomeio de voz interior, me dou conta de que essa voz era definitivamente uma passagem pela qual eu aprendia algo sobre mim mesmo. Algo que, provavelmente, me lembrava de que meu corpo e meu espírito, o orgânico e o espiritual, estão interligados e respondem um ao outro, às vezes, quando a experiência realizada por ambos lhes faz recordar de uma presença mútua. Mutualidade que não aparece, confesso, senáo raramente. 
Eis aqui um dos ensinamentos que Thomas Richards e Mario Biagini puderam me transmitir, mas certamente esse não é o único.

$\mathrm{Na}$ verdade, é uma confissão que devo formular neste momento e que realmente não apareceu até agora nesse estudo. É uma confissáo que deve precisar o lugar de onde eu falo. Há vinte e cinco anos eu exerço a atividade de crítico de teatro. Isso que já foi chamado de monsieur de l'orchestre, quem, durante a noite, após a apresentação, escrevia sobre a peça ou o espetáculo que assistiu. E todo esse tempo em que tenho escrito sobre o teatro, sobre a representação, mas, também, falado com aqueles que dáo vida a essa atividade (os atores, os encenadores, os diretores, etc), me levou a exercer essa atividade com um discernimento que me mantém afastado do julgamento de gosto. Assim, tendo abandonado o julgamento de gosto (a distribuição de boas notas e outras recompensas que traduzem os adjetivos), meu gesto crítico se assemelha mais a um diálogo dramatúrgico. Quer dizer, uma maneira de dialogar com aqueles que tenho seguido, visto e criticado. Por diálogo dramatúrgico, parece-me que conseguimos imaginar que se trata de um modo de estar frente a frente daqueles que observo trabalhar e encenar. Trata-se de descrever o que foi visto, sentido, compreendido... pois a crítica, quando é um diálogo dramatúrgico, assemelha-se em parte a um autorretrato daquele que esteve em contato com uma obra. Ela traduz a relação, a ligaçáo, a intimidade. Ela exprime a relação que aquele que escreve viveu e tem ainda com o objeto que ele viu.

E todo esse tempo dedicado a escrever críticas foi, digamos, uma maneira de buscar, através da escrita, uma arte do encontro e uma arte da distância. Uma arte da distância, pois a palavra crítica, nesse caso, é uma palavra que tenta manifestar e expressar a atenção, o gosto do outro, o cuidado do gesto do outro. É uma palavra que tenta definir da melhor maneira o projeto que estava em jogo. $\mathrm{Na}$ verdade, é a tentativa de dar forma a uma linguagem crítica que se apoia na atençáo, na escuta, no retorno honesto e, por assim dizer, amigável. É uma arte da distância no sentido de que essa linguagem crítica procura não ferir. Trata-se de uma arte da distância, também, pois com o passar dos anos a minha atividade de crítico aprendeu a fugir do teatro banal, do espetáculo cultural. Assim, aprendi a náo falar por nada, quando falar não serve para nada. $O$ gesto crítico aqui descrito é, então, ao mesmo tempo, uma arte da distância e uma arte do encontro. Pois o instante do teatro induz a essa arte do encontro. 
Mas, por mais que eu pratique essa forma crítica que alguns tomam como idealista, e que outros censuram já que ela não representa mais seu papel no jogo social (selecionar, recompensar, aconselhar, avaliar); por mais que esse gesto crítico me pareça o mais apto a falar do que eu vi e do que compreendi, essa prática crítica me mantinha e sempre me manteve fora do teatro. Ela sempre me deixou à margem dessa comunidade que era para mim um objeto de observaçóes e reflexóes. Ela me manteve fora do teatro. Quer dizer, na posição daquele que fala, que comenta, que intelectualiza, que especula. Assim, minhas frases e pensamentos, mesmo sendo o resultado de uma modelagem cuidadosa, foram em vão, pois, verdadeiramente, eu não me guiava por aquilo que via. Incomodado com alguns espetáculos, eu continuava sozinho ou isolado, eu era, creio que seja a melhor palavra, um órfão.

No meio da sala, na minha banqueta, alguma coisa relativa à arte do encontro mudou. Alguma coisa tinha sido transformada. A partir de Living Room, o crítico que eu era foi transformado. Pela primeira vez, eu náo era um estrangeiro, nem um observador do que acontecia. Não, eu fazia parte do processo. Náo somente pelo lugar que ocupava, mas pela linguagem que eu sentia se desdobrar em mim. Uma outra linguagem diferente daquela utilizada pelo crítico que funda a sua crítica na análise Nesse caso, muito mais do que a análise que nos mantém no exterior, porque o órgão solicitado é o cérebro e sua função: a experiência que me foi dada foi a razão. E, através da experiência, foi aquela da linguagem em movimento que se manifestou. Uma linguagem oriunda da experiência, nascida do coração da experiência e cujas regras eram desconhecidas para mim. Uma linguagem que se aplicava à minha consciência e, também, de maneira orgânica, através dos sistemas de signos desorganizados, relativos ao mundo das imagens, às palavras, aos sons e aos espaços desordenados. Uma linguagem desprovida da gramática usual e de seu código único. Uma espécie de linguagem que não é nova, mas impulsionada por um movimento magmático no qual, por fusão, viria, enfim, se manifestar a força e o calor que ela encarna. $E$ isso nada tem a ver com a descoberta de uma linguagem, mas tem a ver com o esquecimento dos possíveis da linguagem. Um pouco como se a experiência de The Living Room forjasse sua própria ferramenta, com o objetivo de refletir, no sentido de tornar visível, sobre o desafio que era a obra durante o encontro. Esse desafio que definirei, em 
uma relação quase existencial, como a relaçáo viva, um esboço vivo de uma forma de ser que se revela a si mesmo. Não uma revelação que poderia ser confundida com um misticismo qualquer. Náo, a revelaçáo da qual se fala aqui se refere àquilo que se é e que náo se consegue mais sentir. No encontro com The Living Room, o esquecimento tinha sido reparado.

No decorrer dessas histórias e no que elas suscitaram, posso dizer hoje que a minha prática como crítico foi enriquecida.

No decorrer dessas histórias, aceitei deixar falar em mim algo que, às vezes, quando pronunciado em público, parece um pouco desestruturado. Sáo coisas que fluem no turbilháo e que a voz carrega. Algo que repousa, ao mesmo tempo, na construção e no imprevisível. E eu não tenho mais medo dessa palavra viva que é a expressão dessa voz interior generosa e portadora de sentimentos. Como se essa palavra, e precisamente essa voz, tivesse seu próprio pensamento. Como se meu corpo tivesse seus próprios pensamentos, como diz Roland Barthes (1973, p. 30).

Assim, em maio de 2012, na Abbaye d'Ardenne, quando foi minha vez de falar, convidado pelo meu amigo Eric Vautrin, novamente abandonei as minhas anotações. E como Mario Biagini estava sentado ao meu lado, em um dispositivo frontal que nos colocava diante do público, no fim da minha apresentação desconstruída que tentava dizer algo, eu me lembro de ter dito, para concluir, me dirigindo a Mario: "Grotowski escreveu um texto, você sabe, se chama Tu es le fils de quelqu'un... Eu não sei de quem sou filho... Mas eu acredito que você, você é um irmáo. Você gostaria que eu te chamasse de meu irmão?” Ocorreu, entâo, um breve silêncio. $\mathrm{O}$ público, eu não duvido disso (e alguns depois vieram me dizer), esperava uma resposta que não era aquela que esperamos ouvir nesses encontros. Ele participou como uma testemunha, eu acho, de algo que desafia a conveniência, os protocolos, as restriçóes que atuam sobre palavras que evitamos sempre tornar impudicas. Ele tinha avaliado, penso, a sinceridade da minha palavra e da minha pergunta. Diante do público, em silêncio, enquanto eu o olhava, Mario Biagini, com um sorriso que é típico dele, me respondeu: "mas você não sabia? Eu sou teu irmão!".

Nessa noite, eu escrevi uma crítica pensando em Thomas e em Mario, no trabalho deles: "nos confins da dança e dos cantos eólicos se mantêm o homem, aquilo que está em pé. O homem é somente presença. Aconteceu algo, acontecerá algo". 


\section{Notas}

${ }^{1}$ Esse tema foi sugerido pelo meu amigo Eric Vautrin, professor na área de Estudos Teatrais na Universidade de Caen. Nessa época, ocorreu uma série de conferências no Institut Mémoire de l'Edition Contemporaine, na Abadia de Ardênia. Na primavera de 2012, Eric Vautrin criou um simpósio sobre a Arte do Encontro, fundamentado especialmente nos arquivos de Jerzy Grotowski (que estão parcialmente depositados no IMEC, na parte concernente a Pontedera. Outros arquivos estáo disponíveis em Wroclaw, na Polônia). Entre os convidados estava o meu amigo Mario Biagini do Workcenter of Jerzy Grotowski. Eu tinha respondido "sim" ao convite e tinha partido de Marselha, onde ensino teatro. Enfim, para ser exato, eu tinha pegado um avião, porque eu estava em Toulouse por razóes profissionais. Eu embarquei de madrugada, cheguei no início da tarde em Caen e estava extremamente cansado, na verdade, esgotado. Então, comecei a falar sobre a Arte da distância. Essa história dialoga com os meus comentários iniciais de que a vida universitária está sempre presente no que se diz.

${ }^{2}$ Arte como veículo é uma das expressões que Peter Brook cunhou para uma das etapas da pesquisa de Jerzy Grotowski. A respeito dessa noção, Peter Brook diz: “[...] a partir do momento em que se começa a explorar as possibilidades do homem, querendo ou náo, tendo medo do que isso representa ou náo, é preciso se posicionar categoricamente diante do fato de que essa pesquisa é uma busca espiritual [...]" (apud Temkine, 1989, p. 11).

${ }^{3}$ Jerzy Grotowski assinara o seu último espetáculo em 1968 (Apocalypsis cum figuris) para logo em seguida se dedicar completamente à sua pesquisa. De 1986 até sua morte (1999) ele fez isso com o apoio da Fondazione Pontedera de Teatro dirigida por Roberto Bacci.

${ }^{4}$ Isso aconteceu logo após a transição representada por One breath left, definido como um espetáculo/não espetáculo, que Thomas Richards e Mario Biagini tinham assumido desde 1998.

${ }^{5}$ Primeiro de 13 de junho a 17 de julho de 2011. Depois, em maio de 2012. Para mais informaçóes sobre o funcionamento do programa, consultar o site do Teatro de Radeau: $<$ http://www.lafonderie.fr/spip.php?rubrique25>.

${ }^{6}$ Um livro testemunha essa experiência inacreditável (Kokowski, 2001).

7 Uma "Ação", segundo o glossário da Academia, define-se do seguinte modo: "[...] o defeito de ser se repara ao fazer" (Académie..., 2001, p. 228). Deve-se a Pierre Henri a existência desse glossário.

${ }^{8}$ Os "Mestres" qualificam-no detentor de um segredo que ele roubou de outro mestre. Os mestres são os pais da Academia "[...] o silêncio deles é inestimável" (Académie..., 2001, p. 228). Entre os mestres, a "mestra da casa" referência que Koko faz de si mesma, eis os que contribuíram com seus conhecimentos Tadeusz Kantor, Jerzy Grotowski, Giorgio Strehler, Heiner Müller, Klaus Mickael Grüber, etc.

${ }^{9}$ Como não fui testemunha da obra cênica de Jerzy Grotowski, mesmo tendo visto muitos filmes que permitam ter uma ideia do processo dramático, eu não posso falar da obra artística do autor. $\mathrm{Na}$ verdade, o espectador fazia parte integral do programa teatral. A restrição que faço é, portanto, de ordem ética. 
${ }^{10}$ Esta prática da crítica que me confere a identidade de crítico dramático acabou por me inserir em uma prática de escrever sobre os espetáculos que assisto. Ou seja, é uma organização da linguagem. Retornarei posteriormente a discutir sobre esse aspecto, principalmente a partir do que me foi transmitido por Michelle Kokosowki, Thomas Richards e Mario Biagini e a partir do que comecei a situar nas histórias contadas.

${ }^{11}$ The Living Room foi apresentada no Théâtre du Radeau-La Fonderie du Mans nos dias primeiro e dois de julho de 2011. Tratava-se de uma forma performativa que procedia do trabalho de Thomas Richards sobre A Arte como veículo. Esse trabalho baseava-se na noção de acolhimento do outro, que é uma ação fundamental e que permite questionar como as potencialidades do ofício performativo podem, às vezes, enriquecer e ser enriquecidas pelas relaçóes e realidades interpessoais cotidianas.

12 Após várias retomadas, a palavra "raiz" vem do pensamento de Jerzy Grotowski. Especialmente quando ele se dá conta da natureza das relaçóes, através de um ser ou de um indivíduo que ao se tornar ator deve cativar e logo após se distanciar do homem moderno que ele é, submisso ao desenvolvimento da sociedade moderna. No período do Teatro Laboratório e de suas pesquisas, Jerzy Grotowski comentará frequentemente a respeito desse "conflito". Pode-se ler frequentemente a seguinte referência: "o homem moderno está separado de suas raízes" (Grotowski, 1968, p. 14).

${ }^{13}$ Jerzy Grotowski explica, então, sua evolução: “[...] após ter estado no período do teatro de espetáculo, nós estivéramos no período do parateatro que terminou em 1978 para começar outra etapa que, para ser compreendida, exigia que se ressaltasse a grande diferença entre workshop, quer dizer atelier ou estágio, e obra-processo. Isso é muito importante de ser compreendido. Se náo há divisão entre o ator-espectador e a ação, e se nós já estamos em curso de fazer emergir uma ação que dure, que se passe durante várias horas, dias e noites, englobando várias pessoas, isso não se trata de um workshop. É uma obra, mas uma obra que está unicamente em processo, ou seja, uma obra-afluente, a obra consigo mesma, a obra dos seres humanos que, ao mesmo tempo, sáo sua substância" (Grotowski, 1978, p. 8).

${ }^{14}$ Cabe-me antecipar não a advertência, mas a crítica dessa abordagem. Em busca de um ponto comum entre o trabalho teatral e os espetáculos, o Teatro Laboratório, as diferentes etapas de sua pesquisa, nós consideramos a ideia de que a interrogaçáo e o questionamento sobre o espectador, seu espaço e seu papel, jamais estiveram fora de questão. Ao reunir diferentes materiais de Jerzy Grotowski, o que nos pareceu, é justamente essa recorrência sobre um questionamento sobre o espectador que, finalmente, não é mais estranho ao trabalho teatral. Mesmo que coloquemos na obra diferentes traços, tomados de uma história complexa feita de estratos e orientaçóes diversas, o que nós desenhamos e pressentimos do trabalho de Jerzy Grotowski é a existência de um pensamento organizado como um arquipélago, no qual os elementos que, às vezes, parecem distantes, no entanto, estáo ligados. E justamente isso que tentamos mostrar.

${ }^{15}$ Nós fazemos referência a uma das fotos que figura no programa do Théâtre-Laboratoire Rzedow 13 editado na apresentação em 1965, do espetáculo O Príncipe Constante, a partir do texto de Calderón, por Jerzy Grotowski, dirigido por Ludwig Flaszen, em Wroclav Rynek Ratusz 27. Os textos do livro foram traduzidos por Jan Blonski. 
${ }^{16}$ Kordian (1962), Akropolis (1962-1965), Doktor Faustus (1963), Le Prince Constant (1965), Apocalypsis cum Figuris (1968).

${ }^{17}$ Jerzy Grotowski, quando fala do espectador, está falando de "testemunha autêntica" (1968, p. 15).

${ }^{18}$ Sobre o canto, pode-se reler a pequena coletânea de textos recolhidos por Georges Banu (1995). E, também, certamente, a contribuição de Ludwig Flaszen (1995).

\section{Referências}

ACADÉMIE Expérimentale des Théâtres Traversées, 1990-2001. Paris: Monum éditions du Patrimoine, 2001.

BANU, George. De la Parole aux Chants. Arles: Actes Sud Papiers et Académie Expérimentale dês Téâtres, 1995.

BARTHES, Roland. Le Bruissement de la Langue. Paris: Seuil, 1984.

BARTHES, Roland. Le Plaisir du Texte. Paris: Seuil, 1973.

DIDEROT, Denis. La Promenade du Sceptique ou les Allées [1747]. Texto estabelecido por J. Assézat. Paris: Garnier, 1875-77. P. 177-250.

FLASZEN, Ludwig. Deux Précurseurs: Bretch et Grotowski. In: BANU, George. De la Parole aux Chants. Arles: Actes Sud Papiers et Académie Expérimentale dês Téâtres, 1995. P. 40-44.

GROTOWSKI, Jerzy (editado por George Banu). L’Art du débutant. International Théâtre Information. Varsóvia, jun. 1978. P. 2-6.

GROTOWSKI, Jerzy. Jerzy Grotowski, le Théâtre et le Rite. Journal France-Pologne Peuples Amis, n. 18-29, p. 12-20, 1968.

GROTOWSKI, Jerzy. Le Prince Constant d'après le texte de Caldéron, par Jerzy Grotowski assisté par Ludwig Flaszen, à Wroclav-Rynek - Ratusz 27. Programme du ThéâtreLaboratoire Rzedow 13, édité à l'occasion de la mise en scène, en 1965. Les textes de la brochure ont été traduits par Jan Blonski.

GROTOWSKI, Jerzy. Tu es le Fils de Quelqu’un. Europe, Paris, n. 726, p. 13-25, 1989.

HÖLDERLIN, Friedrich. Hymnes. In: Hölderlin. Paris: Gallimard, Bibliothèque de la Pléiade, 1967.

KANT, Emmanuel. La Critique de la Faculté de Juger. Paris: Vrin, 1993.

KOKOSOWSKI, Michelle. Académie Expérimentale des Théâtres Traversées, 19902001. Paris: Monum éditions du Patrimoine, 2001.

MISRAHI, Robert. Construction d'un Château, Comment Faire de sa Vie une CEuvre. Paris: Entrelacs, 2006.

NIETZSCHE, Friedrich. La Naissance de la Tragédie. Paris: Gallimard, 1949. 
RICHARDS, Thomas; BIAGINI, Mario. Dossiê de Imprensa do Centre Dramatique National-Comédie de Caen, por ocasião da vinda do Workcenter. In: LACASCADE, Eric (Org.). jun./jul. 2004.

RICHARDS, Thomas. The Edge-point of Performance: entrevista realizada por Lisa Wolford. Pontedera. Séries de Documentaçóes do Workcenter de Jerzy Grotowski, 1997.

TEMKINE, Raymonde. Quid de Grotowski. Europe, "Le théatre ailleurs autrement", Paris, n. 726, p. 10-13, out. 1989.

Yannick Butel é dramaturgo, crítico e professor na Universidade de Aix-Marseille. É autor de diversos livros na área teatral. É editor da revista de estudos teatrais Incertains Regards. É cofundador de L'INSENSÉ, uma plataforma virtual de crítica das artes do espetáculo.

E-mail:

Traduzido do original em francês por Juliana Silva Cruz (Universidade Federal Fluminense) e revisado por Gilberto Icle. Revisão técnica de Tatiana Motta Lima.

Recebido em 06 de outubro de 2012 Aprovado em 12 de dezembro de 2012 